\title{
The Right to Legal and Other Appropriate Assistance for Child Suspects and Accused
}

\section{Reflections on the Directive on Procedural Safeguards for Children who are Suspects or Accused Persons in Criminal Proceedings}

\author{
S.E. Rap
}

Department of Child Law, Leiden Law School, Leiden University, P.o. Box 9520, 2300 RA Leiden, the Netherlands

s.e.rap@law.leidenuniv.nl

\section{Zlotnik}

Department of Child Law, Leiden Law School, Leiden University, P.o. Box 9520, 2300 RA Leiden, the Netherlands

daniella.zlotnik@gmail.com

\begin{abstract}
In this article the development and background of the Directive on procedural safeguards for children who are suspects or accused persons in criminal proceedings is sketched out. Two key rights are reflected upon: the right to legal assistance and the right to other appropriate assistance. The main challenge with regard to the implementation of the right to legal assistance is the possibility of member states to derogate from this right on the basis of the circumstances of the particular criminal case(s) involving the child. The right to legal assistance is contingent upon the proportionality clause that has been built in the Directive and therefore legal assistance is not guaranteed for every child suspect or accused. The right to other appropriate assistance is given separate attention in the Directive, which strengthens the child's legal position and his support during the proceedings.
\end{abstract}

\section{Keywords}

right to legal assistance - other appropriate assistance - Directive 2016/800/EU juvenile justice - children's rights - proportionality 


\section{Introduction ${ }^{1}$}

In May 2016, the European parliament and the Council of the European Union adopted the Directive on procedural safeguards for children who are suspects or accused persons in criminal proceedings (hereinafter Directive on procedural safeguards for children or the Directive). ${ }^{2}$ The Directive is part of the Roadmap for strengthening the procedural rights of suspected or accused persons in criminal proceedings across Europe (hereinafter the Roadmap) ${ }^{3}$ and it is one of six directives coming into force since 2010. It is legally binding on European Union (EU) member states and it should be implemented in national laws and regulations by June 2019. ${ }^{4}$

The aim of the Directive on procedural safeguards for children is to ensure effective protection throughout the $\mathrm{EU}$ of the rights of children who are suspected or accused of having violated the law. ${ }^{5}$ Important underpinnings of the Directive are the recognition of children's (procedural) rights and safeguards and encouraging trust among member states in that regard. Moreover, the Directive builds upon existing international and European legal instruments, such as the UN Convention on the Rights of the Child (hereinafter CRC), ${ }^{6}$ the Charter of Fundamental Rights of the European Union (hereinafter the Charter), ${ }^{7}$ the European Convention for the Protection of Human Rights and

1 This article is partly based on S. Rap, D. Zlotnik, C. van Leeuwen \& T. Liefaard, White Paper on the new EU Directive on procedural safeguards for children. Brussels: International Juvenile Justice Observatory, forthcoming. The authors would like to thank Prof. Ton Liefaard for his valuable comments on an earlier draft of this article and Mike Kastelein, LL.M. for his research assistance

2 Directive (EU) 2016/80o of the European Parliament and of the Council of 11 May 2016 on procedural safeguards for children who are suspects or accused persons in criminal proceedings.

3 Resolution of the Council of 30 November 2009 on a Roadmap for strengthening procedural rights of suspected or accused persons in criminal proceedings, 2009/C 295/01.

4 With the exception of the UK, Ireland and Denmark which are not taking part in the adoption of the Directive and are not bound by it or subject to its application. See in that regard Directive 2016/800/EU, Recitals 69-70.

5 A child is defined as a person below the age of 18 . The Directive also applies to persons who have subsequently reached the age of 18 during the proceedings and to whom the application of the Directive or certain provisions thereof, in the light of all circumstances of the case, is appropriate (Directive 2016/80o/EU, Art. 2 (3)). When the person concerned has reached the age of 21, Member States may decide not to apply the Directive.

6 UN General Assembly, Convention on the Rights of the Child, 20 November 1989, United Nations, Treaty Series, vol. 1577, p. 3

7 European Union, Charter of Fundamental Rights of the European Union, 26 October 2012, $2012 / \mathrm{C}_{326 / 02 .}$ 
Fundamental Freedoms (hereinafter the ECHR), ${ }^{8}$ the European Rules for juvenile offenders subject to sanctions or measures ${ }^{9}$ and the Council of Europe Guidelines on Child-friendly Justice. ${ }^{10}$

This article aims to sketch out the development and background of the Directive, focussing specifically on the right to legal assistance and the right to other appropriate assistance. Two questions are central in this regard; 1) to what extent does the principle of proportionality affect the right to legal assistance for child suspects and accused as laid down in the Directive on procedural safeguards for children? and 2) how is the relation between the right to legal assistance and the right to other appropriate assistance for child suspects and accused conceptualised in the Directive on procedural safeguards for children?

First, in Section 2 the development of children's rights within the context of EU law will be presented. In Section 3, the development and drafting process of the Directive on procedural safeguards for children will be addressed briefly, before turning to the content of the Directive in Section 4. The right to legal assistance and other appropriate assistance, as laid down in the Directive will be analysed in light of the international and European children's rights standards and principles. This article will conclude with a reflection on the influence of the principle of proportionality on the right to legal assistance in the Directive, as well as on the scope and meaning of the right to other appropriate assistance for child suspects and accused, in relation to legal assistance.

In recent years, children's rights have been increasingly addressed in a structured and coordinated fashion in EU legislation and policymaking, whereas in the past it took place in a piecemeal fashion. ${ }^{11}$ The first important step the EU took in embracing children's rights is the introduction of the Charter of Fundamental Rights of the European Union in 2000. The Charter contains specific provisions addressing children's rights, most notably article 24 . This

8 Council of Europe, European Convention for the Protection of Human Rights and Fundamental Freedoms, as amended by Protocols Nos. 11 and 14, 4 November 1950, ETS 5 .

9 Council of Europe: Committee of Ministers, Recommendation $c M / \operatorname{Rec}(2008) 11$ of the Committee of Ministers to Member States on the European Rules for juvenile offenders subject to sanctions or measures, 5 November 2008, Part I.A.2.

10 Council of Europe, Guidelines of the Committee of Ministers of the Council of Europe on Child-friendly Justice, 17 November 2010.

11 European Union Agency for Fundamental Rights, Handbook on European law relating to the rights of the child (Luxembourg: Publications Office of the European Union, 2015). 
provision grants children the right to specific protection and care as is necessary for their well-being, the right to express their views freely (art. 24(1)), the right to have their best interests taken as a primary consideration (art. 24(2)) and the right to maintain a personal relationship and direct contact with parents (art. 24(3)). Other provisions relating to children include the right to receive free compulsory education (art. 14(2)), a prohibition of discrimination on the basis of age (art. 21) and a prohibition of exploitative child labour (art. 32). These provisions are heavily inspired by the CRC (see articles 2, 3, 9, 12, 28 and 32 ) and the ECHR. ${ }^{12}$ Initially, the Charter was merely a declaration of fundamental rights and principles and did not have any binding force. As a consequence of the entry into force of the Lisbon Treaty, ${ }^{13}$ the provisions relating to children in the Charter became more visible and legally binding for the EU and its member states. When failing to comply with the standards of the Charter, including those referring to children's rights and interests, member states and EU institutions can directly be held accountable. ${ }^{14,15}$

Both preceding and following the entry into force of the Lisbon Treaty several initiatives were taken by the EU, on a policy level, to strengthen its children's rights approach. In 2006, the European Commission adopted its first action plan on children's rights in the Communication Towards an EU Strategy on the Rights of the Child. ${ }^{16}$ In 2007, the Council of the European Union adopted the $E U$ Guidelines for the promotion and protection of the rights of the child ${ }^{17}$ and in 2017 the revised EU Guidelines were adopted..$^{18}$ In 2008, the European Commission adopted another Communication; A special place for children in EU external action, which aims to promote the rights of children and prioritise their

12 H. Stalford, Children and the European Union: Rights, Welfare and Accountability (Oxford: Hart Publishing, 2012) p. 40.

13 European Union, Treaty of Lisbon Amending the Treaty on European Union and the Treaty Establishing the European Community, 13 December 2007, 2007/C 306/01.

14 H. Stalford, 'Journeys to European Justice: (How) Can the Eu Enable Children to Enforce their Rights?' in I. Iusmen \& H. Stalford, eds., The EU as a Children's Rights Actor. Law, Policy and Structural Dimensions (Opladen-Berlin-Toronto: Barbara Budrich Publishers, 2016) p. 32; H. Stalford \& M. Schuurman, 'Are We There Yet?: the Impact of the Lisbon Treaty on the Eu Children's Rights Agenda', 19 International Journal of Children's Rights (2011) 381-403, p. 397 .

15 However, it should be noted that the Charter only applies in relation to matters arising under EU law (art. 51(1)). This implies a more limited application than the ECHR, for example.

$16 \operatorname{com}(2006) 367$ final.

17 EU Guidelines for the Promotion and Protection of the Rights of Children 2017.

18 EU Guidelines for the Promotion and Protection of the Rights of Children 2017. 
needs in the E U's external policies. ${ }^{19}$ In 2011, the European Commssion adopted the $E U$ Agenda for the rights of the child, which sets out key priorities for the development and implementation of children's rights law and policy across EU member states. ${ }^{20}$ The $E U$ Action plan on human rights and democracy (20152019) also contains several actions relating to children. ${ }^{21}$ These documents are not legally binding, however, 'they establish the blueprint for the Eu's normative and methodological approach to children's rights law - a blueprint that is firmly associated with the CRC'.22 In the 2011 Agenda for the rights of the child, it is specifically stated that the CRC's provisions and principles must guide EU policies and actions relating to children and their rights. ${ }^{23}$ In 2014, the European Parliament passed the Resolution on the $25^{\text {th }}$ anniversary of the UN Convention on the Rights of the Child, ${ }^{24}$ calling on member states and the EU to better ensure the full implementation of the CRC in policy and practice. The resolution held that member states have 'clear legal obligations to promote, protect and fulfil the rights of every child in their jurisdiction' and that children's rights are at the heart of EU policies. ${ }^{25}$ Moreover, making justice systems in Europe more child-friendly is defined in the 2011 Agenda as a key priority of the European Commission. ${ }^{26}$ Following these developments several EU directives have been adopted, incorporating provisions relating to children. ${ }^{27}$

$19 \operatorname{com}(2008) 55$ final, p. 1.

$20 \operatorname{com}(2011) 60$ final; European Union Agency for Fundamental Rights, op. cit.; H. Stalford (2016), op. cit.

21 EU Action plan on human rights and democracy (2015-2019), adopted at the Foreign Affairs Council 20 July 2017.

22 European Union Agency for Fundamental Rights, op. cit., p. 22.

$23 \operatorname{com}(2011) 6$ o final, p. 3.

24 European Parliament resolution of 27 November 2014 on the 25 anniversary of the UN Convetion on the Rights of the Child, 2014/2919(RSP). For more information, see also M. Tuite, 'Child Right Research for 2040: A European Commission Perspective', in T. Liefaard \& J. Sloth-Nielsen, eds., The United Nations Convention on the Rights of the Child: Taking Stock after 25 Years and Looking Ahead (Leiden-Boston: Brill-Nijhoff Publishing, 2017) pp. 461-488.

25 European Parliament resolution of 27 November 2014 on the 25 anniversary of the UN Convention on the Rights of the Child, 2014/2919(RSP).

$26 \operatorname{com}(2011) 60$ final. See also Council of Europe, Guidelines of the Committee of Ministers of the Council of Europe on Child-friendly Justice, adopted 17 November 2010.

27 See for example the EU Victims Directive (Directive 2012/29/EU) which establishes minimum standards for the protection of vulnerable victims involved in different justice processes, including children. And both the EU Trafficking Directive (Directive 2011/36/EU) and the Eu Sexual Exploitation Directive (Directive 2011/92/EU) aim to harmonise definitions (respectively of trafficking and sexual offences) and provide that legal assistance and support should be guaranteed for children throughout the justice process. 
Every EU member state is party to the CRC, which gives it important standing at the European level. ${ }^{28}$ The main drawback of the CRC is its limited powers of enforcement, apart from the legally binding nature of the Convention at the domestic level. ${ }^{29}$ The growing influence of the CRC on EU legislation, therefore, provides it with more persuasive enforceability in Europe. ${ }^{30}$ However, evidence exists that member states inconsistently and inadequately implement some of the obligations stemming from Eu law. ${ }^{31}$ The true integration of children's rights in EU law asks for effective mechanisms of enforcement. Both Caianiello and Soo have observed the absence of effective remedies in relation to specific procedural rights and safeguards laid down in EU law. ${ }^{32}$ Caianiello even goes as far as to state that the absence of procedural sanctions risks making directives ineffective and that it poses a threat to the proportionality of the legislation. ${ }^{33}$ In this article one step is taken back to examine the influence of the principle of proportionality on the development and the scope of the Directive on procedural safeguards for children more closely, specifically with regard to the right to legal and other appropriate assistance.

\section{The Development of the Directive on Procedural Safeguards for} Children

The international children's rights' agenda has yielded several legal obligations pertaining to the rights, support and protection of children. The Directive on

28 European Union Agency for Fundamental Rights, op. cit., p. 26.

29 Note that in 2011 the $3{ }^{\text {rd }}$ Optional Protocol to the Convention on the Rights of the Child on a Communications Procedure (OP-IC) was adopted (A/RES/66/138), which gives children the possibility to submit individual communications alleging violations of the Convention on the Rights of the Child or its two first Optional Protocols. At the time of writing, 33 countries have ratified and an additional 25 countries has signed the OP-IC. As of yet, four cases are dealt with by the CRC Committee. All four are found inadmissible or are discontinued (see for more information: http://www.ohchr.org/EN/HRBodies/CRC/ Pages/CRCIndex.aspx).

$30 \quad$ H. Stalford \& M. Schuurman, loc. cit., pp. 397-398.

31 See for example N. Kennan \& U. Kilkelly, Children's involvement in criminal, civil and administrative judicial proceedings in the 28 member states of the EU. Policy brief (Luxembourg: Publications Office of the European Union, 2015).

32 M. Caianiello, 'To Sanction (or not to Sanction) Procedural Flaws at EU Level?', 22 European Journal of Crime, Criminal Law and Criminal Justice (2014) 317-329; A. Soo, 'Article 12 of the Directive 2013/48/eu: A Starting Point for Discussion on a Common Understanding of the Criteria for Effective Remedies of Violation of the Right to Counsel', 25 European Journal of Crime, Criminal Law and Criminal Justice (2017) 31-51.

M. Caianiello, loc. cit., p. 321, 324. 
procedural safeguards for children is part of the area of cooperation in criminal matters, in which the Eu has extensive legislative powers. ${ }^{34}$

As mentioned in the introduction, the basis of the Directive on procedural safeguards for children was laid down in the Roadmap for strengthening the procedural rights of suspected or accused persons in criminal proceedings. ${ }^{35}$ This Roadmap is part of the Stockholm programme that sets out the EU's priorities for the area of justice, freedom and security. ${ }^{36}$ The aim of the Roadmap was to harmonise standards for procedural rights, which are necessary in the context of judicial cooperation and to strengthen trust amongst member states in each other's criminal justice systems and thus to improve mutual recognition of decisions in criminal matters. ${ }^{37}$ According to the European Commission, due to the absence of general protections at the Eu level, the right to a fair trial of children and other vulnerable persons was not sufficiently guaranteed. ${ }^{38}$

34 European Union, Consolidated version of the Treaty of the Functioning of the European Union, 13 December 2007, 2008/C 115/o1 (TFEU), Art. 82(2)(b); See also European Union Agency for Fundamental Rights, op. cit., p. 22.

35 Resolution of the Council 2009/C 295/o1. In recent years, on the basis of the Roadmap, six directives have been consecutively adopted, which resulted from the list of five measures anticipated in the Roadmap. These concern the Directive on the right to interpretation and translation in criminal proceedings (Directive 2010/64/EU), the Directive on the right to information in criminal proceedings (Directive 2012/13/EU), the Directive on the right of access to a lawyer in criminal proceedings and European arrest warrant proceedings (Directive 2013/48/EU), the Directive on the strengthening of certain aspects of the presumption of innocence and the right to be present at the trial in criminal proceedings (Directive 2016/343/EU), and the Directive on legal aid for suspects and accused persons in criminal proceedings and for requested persons in European arrest warrant proceedings (Directive 2016/1919/EU).

36 In the aftermath of the 9/11 terror attacks in 2001 the European Arrest Warrant (Council of European Union Decision on the European Arrest Warrant and Surrender Procedure 2002) was adopted by the European Council, in order to ensure judicial cooperation between EU Member States. It allows Member States to extradite wanted persons arrested in another Member State. However, in many cases the European Arrest Warrant was erroneously applied and this resulted in rights violations of persons who had been extradited. As a result, the Stockholm programme was developed Under the Swedish Presidency of the Council of the European Union in 2009, to commit Member States to restoring a proper balance between security and fundamental rights.

37 Resolution of the Council 2009/C 295/o1, Recital 5-8. See also M.A.H. Kempen \& J. uit Beijerse, 'De Eu-Richtlijn procedurele waarborgen minderjarige verdachten en het Nederlandse jeugdstrafprocesrecht', 22 Nederlands tijdschrift voor Europees recht (2016), 230236 ; J.W. Ouwerkerk, 'All 'bout the Money? On the Division of Costs in the Context of eu Criminal Justice Cooperation and the Potential Impact on the Safeguarding of eu Defence Rights', 25 European Journal of Crime, Criminal Law and Criminal Justice (2017) 1-10.

M.A.H. Kempen \& J. uit Beijerse, loc. cit. 
Moreover, the vulnerability of suspected or accused persons was not adequately addressed from the very beginning of the criminal proceedings (e.g. police interrogation, pre-trial proceedings, etc.). Vulnerable persons, in particular children, were also not sufficiently assisted throughout the criminal proceedings; i.e. their access to a lawyer was not ensured. ${ }^{39}$

On 27 November 2013, the European Commission published a Proposal for a Directive on procedural safeguards for children suspected or accused in criminal proceedings. ${ }^{40}$ The Commission pursued two goals with the proposed Directive. ${ }^{41}$ First, to ensure a more homogeneous protection of children's rights in juvenile justice within the $\mathrm{EU}$ in view of improving mutual recognition and judicial cooperation. Second, to promote greater protection of the rights of children in criminal proceedings, especially during the phases in which children are more exposed to risks of harm or undue suffering, such as the initial stages of criminal proceedings. ${ }^{42}$

According to the Commission the proposed Directive on procedural safeguards for children complied with the institutional principles of subsidiarity and proportionality. The principle of subsidiarity, as laid down in article 5(3) Treaty on European Union (hereinafter TEU), ${ }^{43}$ is complied with since the aim of the proposed Directive is to promote mutual trust between member states and it is therefore important to agree on common minimum standards of procedural safeguards for children suspected or accused in criminal proceedings across the EU. ${ }^{44}$ The principle of institutional proportionality (art. 5(4) TEU), ${ }^{45}$ is also complied with because the proposed Directive does not go beyond the minimum required in order to achieve the stated objective at European level and what is necessary for that purpose. ${ }^{46}$ The Commission argued that the proposed Directive is not a measure that would lead to substantial changes of the member state's criminal justice systems, because it only establishes minimum

$39 \operatorname{sWD}(2013) 480$ final.

$40 \quad \operatorname{COM}(2013) 822$.

$41 \operatorname{swD}(2013) 480$ final.

42 D. de Vocht, et al., 'Procedural Safeguards for Juvenile Suspects in Interrogations. A Look at the Commission's Proposal in Light of an EU Comparative Study', 5 New Journal of European Criminal Law (2014) 480-506.

European Union, Consolidated version of the Treaty on European Union, 26 October 2012, C 326/16 (TEU). The principle of subsidiarity implies that the EU can only intervene in national law when it can do so more effectively compared to individual member states at the national or local level (art. $5 \mathrm{TEU}$ ).

$44 \operatorname{COM}(2013) 822$, Recital 72, 73. Directive 2016/80o/EU, Recital 67.

45 The principle of proportionality implies that the EU intervention must be proportionate to the goal one pursues with the intervention.

$\operatorname{COM}(2013)$ 822, Recital 72, 73. Directive 2016/80o/EU, Recital 67. 
rules, that are considered indispensable to meet the objective of achieving an effective standard of protection for children and to enhance mutual trust and judicial cooperation. ${ }^{47}$

The negotiations between the European Parliament and the Council on the Directive started in February 2015. ${ }^{48}$ The right to access to a lawyer turned out to be one of the most difficult issues. Some member states were concerned that the practical implementation at national level of this right would cause difficulties and therefore, several provisions, such as the right to the assistance by a lawyer ${ }^{49}$ and the requirement of audio-visual recording of interrogations ${ }^{50}$ were made contingent upon an individual proportionality assessment, on the basis of the circumstances of the case, the seriousness of the alleged criminal offence, the complexity of the case and the measures that could be taken with regard to the child. ${ }^{51} \mathrm{~A}$ general point of concern relating to the implementation of the Directive on procedural safeguards for children is the fact that it does not apply to certain minor offences that are not considered criminal (e.g. road traffic offences).$^{52}$ This means that member states can decide that certain offences are categorically ruled out from application of the Directive. These procedures, however, can result in significant sanctions and criminal records and children should be entitled to certain minimum safeguards in these procedures as well. In the following section, the implications of the individual proportionality assessment in relation to the right to legal and other appropriate assistance will be further examined.

\section{The Right to Legal and Other Appropriate Assistance}

The right to legal assistance ${ }^{53}$ is one of the most important procedural safeguards of the right to a fair trial for both adults and children and is considered a

47 Idem.

48 In application of Art. 294 TFEU, see also S. Cras, 'The Directive on Procedural Safeguards for Children who Are Supstects or Accused Persons in Criminal Proceedings, Genesis and Descriptive Comments Relating to Selected Articles', 2 eucrim (2016) 109-119.

49 Directive 2016/800/EU, Art. 6(6); 6(8).

50 Directive 2016/80o/EU, Art. 9(1).

51 S. Cras, loc. cit. See Directive 2016/80o/EU, Art. 6(6).

$5^{2}$ Directive 2016/80o/EU, Art. 2(6), Recital 14-16; D. de Vocht, et al., loc. cit., p. 499.

53 As will be described below, international and Eurpean instruments and case-law refer to legal assistance, access to a lawyer, and assistance by a lawyer interchangeably. These 
fundamental human right. ${ }^{54}$ Due to children's vulnerability and special needs, their right to legal assistance carries particular significance. ${ }^{55}$ Assistance by a lawyer is meant to safeguard the rights and interests of children throughout all stages of the criminal proceedings and is viewed as a prerequisite of childfriendly justice. ${ }^{56}$ However, the incorporation of the right to legal assistance in the Directive on procedural safeguards for children gave rise to lengthy debates and negotiations between the member states during the drafting process. To further understand the implications of this fundamental right - and the related right to other appropriate assistance - the impact of the proportionality clause on this right will be assessed in this section.

\subsection{Legal Assistance}

The right to legal assistance is anchored in various international instruments. The International Covenant on Civil and Political Rights (hereinafter ICCPR) provides the right of the person to defend himself or herself in person or through legal assistance. ${ }^{57}$ Specifically in relation to children, the United Nations Standard Minimum Rules for the Administration of Juvenile Justice ('Beijing Rules') particularly note the rights of children to be represented by a legal advisor throughout the proceedings. ${ }^{58}$ The CRC provides children the right to 'legal or other appropriate assistance'. Such assistance should be appropriate according to the circumstances of the case and the needs of the child. ${ }^{59}$ In the

terms can, at certain contexts, carry different meanings and require additional obligations. Yet, due to the scope of this article, this will not be elaborated upon.

See ECtHR, Salduz v. Turkey, no. 36391 /o2 (27.11.2008); ECtHR, Panovits v. Cyprus, no. 4268 /04 (11.12.2008).

55 See also T. Liefaard, Child-friendly justice: protection and participation of children in the justice system, 88 Temple Law Review (2016) 905-927; T. Liefaard \& U. Kilkelly, 'Childfriendly justice: past, present and future', in B. Goldson, ed., Juvenile justice in Europe: Past, present and future (New York/London: Routledge, forthcoming).

$5^{6}$ ECtHR, Güveç v. Turkey, par 31, no. 70337/o1 (20.1.2009); See also ECtHR, s.c. v. United Kingdom, no. 60958/oo (15.6.2004), in which ECtHR considers that the shortcomings, including in particular the lack of legal assistance for most of the proceedings, worsened the consequences of the applicant's inability to participate effectively in his trial and infringed his right to due process. On the role of the lawyer in various stages of the proceedings, see also International Juvenile Justice Observatory, Can Anyone Hear Me? Participation of Children in Juvenile Justice: A Manual on How to Make European Juvenile Justice Systems Child-Friendly (Brussels: IJjo 2016), p. 47, 49-52.

57 Art. 14(d) ICCPR.

58 Art. 15.1 Beijing Rules.

59 Art. 40(2)(b)(ii) CRC; CRC GC 10, par. 49-50. 
event that the child is deprived of his liberty, he ${ }^{60}$ should have the right to legal and (emphasis added) other appropriate assistance (see further below). ${ }^{61}$

In the European context, the ECHR provides every person with the right to a fair trial and to legal assistance. ${ }^{62}$ The European Court of Human Rights (hereinafter ECtHR) has specifically underscored the importance of this right for children and found that it should be applied from the outset of the proceedings. Thus, in the case of Salduz v. Turkey the ECtHR held that in order for the right to a fair trial under article 6, part 1 , to remain sufficiently practical and effective [..], access to a lawyer should be provided, as a rule, from the first interrogation of a suspect by the police [...] ${ }^{63}$ In Panovits v. Cyprus, the ECtHR further held that states have a positive obligation to inform child suspects that they can access a lawyer, free of charge if necessary, and ensure that they understand this right. ${ }^{64}$ The right to a lawyer has also been established in Directive 2013/48/EU, ${ }^{65}$ which ensures the right of suspects and accused persons to access, meet and communicate with a lawyer from the outset of the proceedings. ${ }^{66}$ Directive 2013/48/EU does not explicitly refer to children, but it notes in its recital that it 'promotes the rights of children' and takes into account the Council of Europe Guidelines on Child-friendly Justice. ${ }^{67}$ In addition, Directive 2013/48/EU requires that the particular needs of vulnerable suspects are taken into account in its application. ${ }^{68}$

The Directive on procedural safeguards for children provides children with the right to have access and be assisted by a lawyer in accordance with Directive 2013/48/EU and requires member states to enable such access and ensure children are able to exercise their right to defence effectively. ${ }^{69}$ The Directive on procedural safeguards for children defines assistance by a lawyer as 'legal support and representation by a lawyer during criminal proceedings', and it entails similar obligations to those under Directive 2013/48/EU. ${ }^{70}$ Under the Directive on procedural safeguards for children, access to a lawyer must be

6o For the purpose of uniformity it is chosen to refer to persons with 'he' or 'him', while meaning 'she' or 'her' as well.

61 Art. 37(d) CRC.

62 See Art. 6(3)(c) ECHR; Art. 47-48 European Union, Charter of Fundamental Rights of the European Union, 26 October 2012, 2012/C 326/o2.

63 ECtHR, Salduz v. Turkey, par. 55, 60, no. 3691/02 (27.11.2008)

64 ECtHR, Panovits v. Cyrpus, par. 72, no. 4268/04 (11.3.2009).

65 Directive 2013/48/EU.

66 Directive 2013/48/EU, Art. 3(1-2).

67 Directive 2013/48/EU, Recital 55 .

68 Directive 2013/48/EU, Art. 13.

69 Directive 2016/800/EU, Art. 6(1-2), Recital 25.

70 Directive 2016/800/EU, Art. 6(4), Recital 26. Directive 2013/48/EU, Art. 3(3). 
provided without undue delay and from the earliest stages of the proceedings; before questioning by police or other competent judicial authority, upon carrying out investigation or evidence-gathering acts, after deprivation of liberty, or where children are summoned before court in criminal matters; in due time before they appear. ${ }^{71}$ Assistance by a lawyer shall include the right to meet in private and communicate with the lawyer, even before interrogation by the police, and it requires that the lawyer is able to assist and participate effectively. The Directive also requires, at a minimum, that children are assisted during particular evidence-gathering or investigative acts; i.e. an identity parade, confrontation and reconstruction of the scene of the crime. ${ }^{72}$ These acts constitute a critical point in the investigation process and so justify additional safeguards and assistance.

\subsection{Challenges to the Right to Legal Assistance}

Regarding the right to legal assistance the scope of the Directive can be seen as somewhat limited as it allows for derogation from this right, on the basis of an individual case-by-case proportionality assessment. This is particularly relevant in comparison to the 2013 Proposal of the Directive, which required 'mandatory access to a lawyer' for child suspects or accused and did not allow children to waive this right. ${ }^{73}$ However, in its final version, the Directive only mandates assistance by a lawyer in situations in which a decision is taken to deprive the child of his liberty and during detention and it otherwise enables children to waive the right, on the basis of Directive 2013/48/EU, seemingly irrespective of their age and maturity. ${ }^{74}$ This position is in accordance with ECtHR case law which recognises children's ability to waive their right to a lawyer, given that the waiver is unequivocal, voluntary and that the waiver procedure includes specific safeguards. ${ }^{75}$ Thus, a waiver must be in accordance

71 Directive 2016/80o/EU, Art. 6(3)(a-d).

72 Directive 2016/80o/EU, Art. 6(4)(a-c), Art. 6(5).

73 Art. 6(1) Proposal for a Directive of the European Parliament and the Council on Procedural safeguards for children suspected or accused in criminal proceedings, Сом(2013) 822 final (2013); Art. 26-27 Proposal Explanatory Memorandum.

74 However, Directive 2013/48/EU Art. 13 provides that 'Member States shall ensure that the particular needs of vulnerable suspects and vulnerable accused persons are taken into account in the application of this Directive'.

75 See ECtHR, Panovits v. Cyrpus, no. 4268/04 (11.3.2009); ECtHR, Zherdev v. Ukraine, no. 34015/07 (27.4.2017). See also T. Liefaard, 'Zherdev v. Ukraine: Article 3 of the EсHR and Children's Rights at the Stage of Police Interrogation', Strasbourg Observers Blog (29.6.2017), Availabe online: https://strasbourgobservers.com/2017/06/29/zherdev-v -ukraine-article-3-of-the-echr-and-childrens-rights-at-the-stage-of-police-interrogation/ (accessed 18.7.2017). 
with the conditions set in the Directive 2013/48/EU. These include, among others, that the suspect or accused person received orally or in writing, clear and sufficient information in simple and understandable language about the right to access a lawyer and the possible consequences for waiver, that the waiver is given voluntarily and unequivocally and that it is possible to revoke the waiver at any point during the criminal proceedings. ${ }^{76}$ Yet, children's ability to waive the right to legal assistance can raise serious concerns and these are not adequately addressed under the Directive. Research has shown that children, due to their age and (developing) maturity, cognitive and emotional skills, can have difficulties to fully understand their rights and to participate in criminal proceedings. ${ }^{77}$ Allowing, particularly younger children, to waive their right to access a lawyer and to legal assistance can be harmful to their rights and interests and may result in extra pressures from law enforcement agencies on children and/or their parents. ${ }^{78}$

Second, the Directive derogates the right to legal assistance on the basis of proportionality. Article 6(6) of the Directive enables member states to derogate from the right if assistance by a lawyer 'is not proportionate in light of the circumstances of the case', taking into account the seriousness of the alleged criminal offence, the complexity of the case and the measures that can be taken, with the best interests of the child as primary consideration. ${ }^{79}$ This is particularly relevant with regard to diversionary measures that can be taken in most national juvenile justice systems in less serious cases, to avoid a formal juvenile criminal procedure and possibly a formal conviction. Other derogations can also be found in article 6(8) where in exceptional circumstances and only in the pre-trial stage, member states may temporarily derogate from the right to legal assistance to allow interrogation or investigative acts if there is an urgent need or if an immediate action is required. ${ }^{80}$ Also, the Directive

76 Directive 2016/80o/EU, Art. 6(6); Directive 2013/48/EU, Art. 9 and Recitals 39-41. Recital 55 of Directive 2013/48/EU explicitly states that suspects and accused persons, including children, are provided with adequate information to understand the consequences of waiving a right under the directive and that any such waiver is made voluntarily and unequivocally; De Vocht et al., New Journal of European Criminal Law 2014, p. 496.

E. Buss, 'What Stands in the Way of Children's Exercise of their Criminal Procedural Rights in the United States? Our Evolving and Incomplete Interdisciplinary Understanding' in M.D. Ruck, M. Peterson-Badali \& M. Freeman, eds., Handbook of Children's Rights. Global and Multidisciplinary perspectives (New York/London: Routledge 2017), pp. 278-295.

78 T. Liefaard \& U. Kilkelly, loc. cit.; T. Liefaard \& Y.N. van den Brink, 'Juveniles' right to counsel during police interrogations: An interdisciplinary analysis of a youth-specific approach, with a particular focus on the Netherlands', 7 Erasmus Law Review (2014) 206-218; T. Liefaard 2017, loc.cit.

79 Directive 2016/80o/EU, Art. 6(6).

8o Directive 2016/80o/EU, Art. 6(8). 
does not apply in certain evidence-gathering acts, such as identifying the child, checking whether he carries weapons, conducting body-checks or physical examinations, blood or alcohol tests or the taking of photographs or finger prints, ${ }^{81}$ despite the fact that these acts can have a significant impact on the criminal procedure and on the child. While the provisions covering the derogations are limited in terms (e.g. 'exceptional circumstances') and require that the best interests of the child are taken into account, the criteria are not clearly formulated and allow for a significant derogation of the right to be assisted by a lawyer. ${ }^{82}$ Moreover, these assessments (i.e. the circumstances of the case, the seriousness of the alleged criminal offence, the complexity of the case and the measures that could be taken), which are very complex, are in practice conducted by police officers and/or deputy prosecutors who, in most cases, are not adequately trained to weight and analyse the best interests of the child in the particular case. Moreover, concerns relating to intensity and complexity of the case can change throughout the course of the proceedings and re-assessments of the case may be neccesary. ${ }^{83}$ At the international level, the CRC Committee has stated, however, that according to article $40(2)(\mathrm{b})(\mathrm{ii})$ CRC the assistance, provided to the child is not neccesarily legal assistance. ${ }^{84}$ Expert lawyers or paralegal professionals are strongly recommended, but other appropriate assistance is also possible, when that person possesses sufficient legal knowledge and is trained in working with children. ${ }^{85}$ Moreover, diversion from formal legal proceedings is strongly advocated for in the CRC, which might entail in certain national juvenile justice systems that legal assistance is not provided. The CRC Committee holds the opinion that in case of diversion children's human rights and legal safeguards should be fully respected and that the child should have the opportunity to seek legal or other appropriate assistance in the process of accepting the diversionary measure..$^{86}$

The individual application of the principle of proportionality also arises in the context of article 9 of the Directive, which requires audio-visual recording of police questioning where this is proportionate in the circumstances of the case, taking into account 'whether a lawyer is present or not and whether the child is deprived of liberty or not' ${ }^{\prime 7}$ Audio-visual recordings are an objective

81 Directive 2016/800/EU, Art. 12(5), Recital 28.

82 See Edelman, EU Law Analysis 2015.

83 McVeigh, EU Directive on procedural safeguards for children 2017.

84 CRC GC 10, para. 49-50.

85 CRC GC 10, para. 49 .

86 CRC GC 10, para. $26-27$.

87 Directive 2016/800/EU, Art. 9(1), Recital 42. Moreover, in case of an insurmountable technical problem and provided that reasonable efforts have been made to overcome the technical problem and when it is not appropriate to postpone the questioning, and 
and increasingly affordable measure that can enable courts to evaluate the child's statements, confirm the interrogation was conducted in a child-friendly manner, using language the child understands, and ensure no improper measures were taken by law enforcement. ${ }^{88}$ In practice, however, member states are not obliged to audio-visually record police interrogations in case a lawyer was present or when the child was not deprived of his liberty. However, it can be argued that in more serious cases - in which a child is deprived of his liberty and a lawyer is present during the interrogation - a recording of the interrogation is desirable in any event, because of the more serious consequences that could follow for the child, for example regarding the disposition. Yet, as discussed, this proportionality assessment can result in fewer recordings of interrogations and it has been argued that it introduces a wide scope of discretion and needlessly weakens the protection under the Directive. ${ }^{89}$ For this reason, the use of audio-visual recordings requires clear guidance that addresses the principle of proportionality, as well as other important issues, such as data collection and storage, privacy concerns and professional training in relation to the interpretation and use of the recordings.

To conclude, the Directive on procedural safeguards for children also requires that member states provide effective legal aid in national law. The right to legal aid is 'inextricably linked' with the right to access to a lawyer, but as the subject of legal aid is established in a separate Directive ${ }^{90}$ the provision found in Directive 2016/80o/EU is minimal. ${ }^{91}$ While the Directive on legal aid does not require member states to establish mandatory legal aid, it does ensure that suspected or accused persons who lack sufficient resources to pay for assistance of a lawyer shall have the right to legal aid 'when the interests of justice so require' and holds that member states consider the needs of vulnerable suspects. ${ }^{92}$ Yet, establishing an obligation to provide free legal assistance to every

compatible with the child's best interests, questioning can also take place without audiovisual recording it (Recital 43).

88 T. Liefaard 2016, loc. cit; T. Liefaard \& U. Kilkelly, loc. cit.

89 M.W. Edelman, 'Standing up for Children? The Directive on Procedural Safeguards for Children Suspected or Accused in Criminal Proceedings', EU Law Analysis (22.12.2015). Available on http://eulawanalysis.blogspot.nl/2015/12/standing-up-for-children-directive -on.html (last accessed, 5.4.2017).

90 Directive on legal aid for suspects and accused persons in criminal proceedings and for requested persons in European arrest warrant proceedings (Directive 2016/1919/EU).

91 D. de Vocht et al, loc. cit., p. 499.

92 Directive 2016/1919, Art. 4(1-2), Art. 9; See also D. de Vocht et al, loc. cit., p. 499. Interestingly, the Guidelines on Child-friendly Justice do not provide for free legal aid (T. Liefaard \& U. Kilkelly, loc. cit.). 
child suspect and accused could have strengthened the right of children to be assisted by a lawyer. ${ }^{93}$

This analysis shows that as a result of the possibility to apply a proportionality assessment, children are not unequivocally entitled to legal assistance when suspected or accused of a criminal offence. In the following section, therefore, another important procedural safeguard for child suspects and accused under the Directive, the right to other appropriate assistance, will be analysed.

\subsection{Other Appropriate Assistance}

As stated above, a distinction can be made between legal and other appropriate assistance. The CRC strictly requires legal assistance in case a child is deprived of his liberty. ${ }^{94}$ According to the CRC Committee, the right to legal or other appropriate assistance is vital to the right of the child to participate in the juvenile justice process. ${ }^{95}$ Other appropriate assistance may entail assistance by a social worker or other professionals, but these persons need to have sufficient knowledge and understanding of the legal aspects of the juvenile justice process. ${ }^{96}$

A second related issue concerns the role of parents or legal guardians in the proceedings. Parental assistance can be seen as a form of 'other appropriate assistance' as well. The CRC provides that the child is entitled to the presence of 'other appropriate assistance', in particular his parents or legal guardians, unless it is considered not to be in the best interests of the child ${ }^{97}$ According to article $40(2)(\mathrm{b})(\mathrm{ii}) \mathrm{CRC}$ parents can also play a role in informing the child about the charges against him. The CRC Committee recognises that parents can provide 'general psychological and emotional assistance' to the child and has recommended states parties to enable the 'maximum possible involvement' of parents in the legal proceedings. ${ }^{98}$ By noting the special benefits of the assistance by parents (psychological and emotional assistance), the CRC Committee makes a clear distinction between the role of legal assistance and of parents in the proceedings. Other international standards also recognise parents as key actors in all stages of the criminal proceedings. This includes their involvement in preventive measures, right to be present in the investigation stages, right to accompany the child in court proceedings and their role

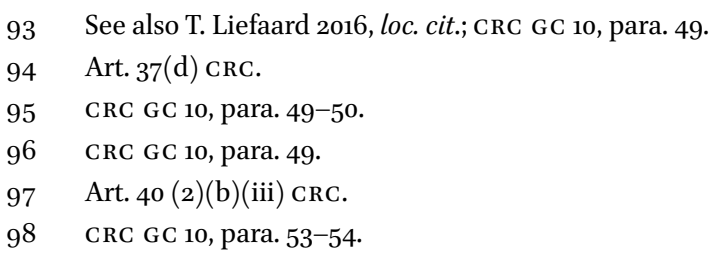


in relation to detention and disposition stages. ${ }^{99}$ Thus, parents can be seen as having a critical role in providing emotional support, guidance and practical assistance to children within the juvenile justice system. ${ }^{100}$

The Directive on procedural safeguards for children defines 'holder of parental responsibility' (hereinafter parents) as any person having parental responsibility over a child. ${ }^{101}$ The Directive grants the holders of parental responsibility three main rights: to receive information, to accompany the child in criminal procedures and to request a medical examination. First, the Directive requires member states to provide parents with the same information the child has the right to receive under the Directive (e.g. right to assistance by lawyer, right to medical examination, etc.). ${ }^{102}$ The right of parents to receive information, as anchored in international standards, should not be viewed as an alternative to communicating information to the child directly. ${ }^{103}$ According to the Directive, the information shall be provided to another appropriate adult, who is nominated by the child, and accepted by the competent authority, in case providing the information to the parent would be contrary to the best interests of the child, if the parent is unknown or cannot be reached, or if informing the parent can 'on the basis of objective and factual circumstances' substantially jeopardize the criminal proceedings (e.g. destroying evidence, interference in the proceedings). ${ }^{104}$ This clause enables the child to choose an appropriate adult to support and assist him throughout the criminal proceedings and recognises that in certain situations parents might also have a negative effect on children's participation and well-being (see below). Where the adult nominated by the child is not acceptable to the competent authority, it can inform another person, as well as the welfare or child protection authorities. ${ }^{105}$ If and when these circumstances cease to exist, the parent should be notified and informed accordingly. ${ }^{106}$

See Art. 7.1, 15.1, 15.2 Beijing Rules, CRC GC 10, para. 18-19, 53-54, 58; Art. 16 Riyadh Guidelines; for overview see IJjo Manual on Child Friendly Justice 2016, pp. 54-56.

100 S.E. Rap, The participation of juvenile defendants in the youth court. A comparative study of juvenile justice procedures in Europe (Amsterdam: Pallas Publications 2013).

101 'Parental responsibility' means all rights and duties relating to the person or the property of a child which are given to a natural or legal person by judgment, by operation of law or by an agreement having legal effects, including rights of custody and rights of access, Directive 2016/800/EU, Art. 3(2-3).

102 Directive 2016/800/EU, Art. 5(1).

103 CRC GC 10, para. 10, 48. Guidelines on Child-friendly Justice, para. IV(A)(1), (3), (5).

104 Directive 2016/800/EU, Art. 5(2)(a-c), Recital 23.

105 Directive 2016/800/EU, Art. 5(2), Recital 23.

106 Directive 2016/80o/EU, Art. 5(3), Recital 24. 
Second, the Directive awards children the right to be accompanied by their parents during the stages of the criminal proceedings. This is a 'traditional' youth-specific safeguard in juvenile justice. ${ }^{107}$ It is a right of the child, based on the presumption that parents are generally best placed to support the child, enhance his participation and contribute to his right to a fair trial. ${ }^{108}$ The Directive ensures children the right to be accompanied by parents to court hearings in which they are involved, as well as to other stages of proceedings (e.g. police interrogation) in such cases where the child is present and the competent authority considers that it is in the child's best interests to be accompanied by the parent and that their presence will not jeopardize the criminal proceedings. ${ }^{109}$ Similarly to the provision regarding the right to information of the parent; the Directive guarantees the right of the child to be accompanied by another appropriate adult that the child nominates and is accepted by the competent authority, where the presence of the parent would be contrary to the child's best interests, when the parent is unknown or cannot be reached or where there are objective and factual circumstances to suggest that the presence of the parent substantially jeopardizes the criminal proceedings. When such circumstances cease to exist, the child shall have the right to be accompanied by the parent. ${ }^{110}$

Third, children who are deprived of their liberty have a right to medical examination to assess their general mental and physical condition. ${ }^{111}$ The Directive enables parents (along with the child and the child's lawyer) to request such medical examination to be performed by a physician or another qualified professional. ${ }^{112}$ In that regard, it should be noted that the Directive also requires member states to ensure children deprived of their liberty can meet with parents as soon as possible, where such a meeting is compatible with investigative and operational requirements. ${ }^{113}$

\subsection{Relation between Legal and Other Appropriate Assistance}

It is positive to note that in the Directive on procedural safeguards for children a distinction is made between the right to legal assistance and the right to the assistance and presence of parents or appropriate adults in the proceedings.

\footnotetext{
107 De Vocht et al., loc. cit., p. 494.

108 CRC GC 10, para. 40, 53-54, 58.

109 Directive 2016/80o/EU, Art. 15(1), 15(4); Recital 57, 59.

110 Directive 2016/80o/EU, Art. 15(2-3), Recital 58.

111 Directive 2016/80o/EU, Art. 8(1).

112 Directive 2016/80o/EU, Art. 8(3)(b), Recital 41; See also De Vocht et al., loc. cit., p. 494-496.

113 Directive 2016/800/EU, Art. 12(6).
} 
This means that both rights apply and that children are not forced to choose between either parental support or legal assistance. ${ }^{114}$ Note that in the CRC the distinction is made between legal or other appropriate assistance, ${ }^{115}$ which implies that child suspects and accused can be represented by a non-legal or paralegal professional instead of a legal representative. ${ }^{116}$ In the Council of Europe Guidelines on Child-friendly Justice it is stated as well that ' $[a]$ child ... should not be questioned ... except in the presence of a lawyer or one of the child's parents'.117 This does not rule out the possibility that the presence of a lawyer could be denied if a parent is present. The CRC Committee has argued, however, that " $\mathrm{t}]$ he child being questioned must have access to a legal or other appropriate representative, and must be able to request the presence of his/ her parent(s) during questioning.'118 With regard to deprivation of liberty, however, article 37(d) CRC provides for legal and other appropriate assistance. This implies that when a child is deprived of his liberty he should be entitled to a higher degree of assistance. ${ }^{119}$

The Directive on procedural safeguards for children provides that parents can be denied access to information and the proceedings in certain circumstances in which it is contrary to the best interests of the child or when the parent may jeopardises the proceedings. ${ }^{20}$ This is in line with the argument that parental involvement can also have a negative effect on children, for example when parents trivialise their child's behaviour. Moreover, the child can experience feelings of shame and fear during the proceedings. Therefore, the best interests of the child may require that parents are not present at all times. ${ }^{121}$ It can be argued that the child should have the possibility to waive his right to have his parents present, for example during a police interrogation. ${ }^{122}$ Both the CRC Committee and the Beijing Rules acknowledge that it should be possible

\footnotetext{
114 T. Liefaard 2016, loc. cit.

115 Art. 40(2)(b)(ii-iii) CRC.

116 CRC GC 10, para. 49-50.

117 Guidelines on Child-friendly Justice, para. $\operatorname{IV}(\mathrm{C})(30)$.

118 CRC GC 10, para. 58. See also T. Liefaard \& U. Kilkelly, loc. cit.

119 T. Liefaard, Deprivation of liberty of children in light of international human rights law and standards (Antwerpen/Oxford/Portland: Intersentia, 2008).

120 Directive 2016/80o/EU, Art. 15(2), 15(4); Recital 58, 60.

121 See for example K. Hepping \& I. Weijers, Effectieve ouderparticipatie in het jeugdstrafproces. De Utrechtse pilot Versterken Betrokkenheid Ouders (Amsterdam: SWP, 2011); M. Peterson-Badali \& J. Broeking, 'Parents' involvement in the youth justice system: Rhetoric and reality, $5_{2}^{2}$ Canadian Journal of Criminology and Criminal Justice (2010) 1-27.

122 See for the role of parents during interrogations T. Liefaard \& Y.N. van den Brink, loc. cit.
} 
to limit or exclude the presence of parents in proceedings. ${ }^{123}$ The Directive explicitly provides for the presence of another appropriate adult and the provision of information to an appropriate adult, ${ }^{124}$ in case the parent cannot be present. ${ }^{125}$ Children have the right to choose their appropriate adult, but the competent authority needs to approve the child's choice and it can also contact and involve welfare or child protection authorities in that regard. ${ }^{126}$

\section{5}

\section{Conclusions}

The Directive on procedural safeguards for children is an important tool in strengthening the legal position of child suspects and accused in Europe, because it provides for binding legislation within the EU. ${ }^{127}$ Moreover, principles enshrined in binding and non-binding standards, such as the CRC, the case law of the ECtHR and the Council of Europe Guidelines on Child-friendly Justice, have been included in the Directive. By adopting this directive, the Eu not only contributes to the promotion of mutual trust and cooperation within its member states, but it also sets minimum standards for EU juvenile justice systems and stipulates that child suspects and accused are entitled to be treated fairly, with respect for their diginity as a human being and in a manner that takes into account their needs and vulnerabilities. ${ }^{128}$ This Directive fits within the development in the $\mathrm{EU}$ in which children's rights are given a more prominent position, through agenda-setting and policymaking, but also by issueing binding legislation.

One of the key features of the Directive on procedural safeguards for children as a whole is the emphasis on protecting rights and providing safeguards at the earliest stages of proceedings when suspected and accused children are most vulnerable. However, two observations can be made with regard to the implementation of the right to legal and other appropriate assistance. First, member states have the possibility to derogate from certain obligations as set forth in the Directive, on the basis of the circumstances of the case (taking into account the seriousness of the alleged offence, the complexity of the case and

\footnotetext{
123 CRC GC 10, para. 53; Rule 15.2 Beijing Rules.

124 Directive 2016/80o/EU, Art. 15(2), Recital 23.

125 Directive 2016/80o/EU, Art. 15(2), Recital 23.

Directive 2016/80o/EU, Art 15(2), Recital 58, 6 o.

126 Directive 2016/800/EU, Art. 5(2), 15(2).

127 De Vocht et al., loc. cit.

128 Art. 40(1) CRC.
} 
the measures that could be taken). This means that on the basis of an individual case-by-case proportionality assessment the right to legal assistance can be withhold for child suspects who are interrogated by the police. Moreover, in case of certain evidence-gathering acts, which can potentially be instrusive and impactful on the child, legal assistance is also not provided for. This means that the right to be assisted by a lawyer - as a minimum standard - is not guaranteed in Europe for every child suspect and accused. The CRC Committee does not regard this as problematic in itself, because other appropriate assistance may be sufficient to protect the rights of the child. Yet, as described above, the proportionaly assessment requires clear guidance to ensure it is not abused, and that law enforcement authorities fully respect the principle of the best interests of the child when considering any derogations from the child's rights and procedural safeguards. Certain other rights are made contingent upon the proportionality assessment clause that has been built in the Directive as well. For example, audio-visual recording of questioning of children by the police is made dependent upon the presence of a lawyer and whether the child is deprived of his liberty. However, it can be argued that in more serious cases a recording of the interrogation is desirable in any event, because of the more serious consequences of the case for the child.

Second, the Directive provides a further conceptualisation of the right to other appropriate assistance, compared to the existing legal standards. Other appropriate assistance is seen as separate from legal assistance, which strengethens the legal safeguards and protections for child suspects and accused and recognises the important role of parents, as well as other non-legal support, for children. Moreover, a distinction is made between parents and other appropriate adults, taking into account the fact that parents may not always be available or suitable to participate in the proceedings. Therefore, it can be concluded that the Directive further strengthens the position of other appropriate adults in juvenile justice proceedings, alongside legal assistance and provides children with stronger support mechanisms.

To conclude, the Directive on procedural safeguards for children provides minimum standards and EU member states are free to provide higher levels of protection to child suspects and accused. ${ }^{129}$ In this regard, it is recommendable to strive for a higher level of protection, building upon other European and international standards. Ensuring mandatory legal assistance to children free of charge and ruling out the possibility of waiving the right to legal assistance would further enhance the effective exercise of their rights and protections while being in a particular vulnerable position. When following

129 See also Art. 82(2) TFEU. 
the argument that the child's best interests should always be a primary consideration ${ }^{130}$ it can be concluded that providing legal assistance to child suspects and accused should be guaranteed for every child and during all stages of the criminal procedure.

130 Art. 3 CRC; Art. 24(2) European Union, Charter of Fundamental Rights of the European Union, 26 October 2012, 2012/C 326/o2; Directive 2016/80o/EU, Art. 6(6); Directive 2016/800/EU, Recital 8, 30 . 